\title{
Cointegration analysis of stock market index and exchange rate: the case of Serbian economy
}

\section{Коинтеграциона анализа тржишног индекса и девизног курса: случај српске економије}

\author{
Milena Marjanović \\ Academy of Vocational Studies Southern Serbia, Leskovac, Republic of Serbia, marjanovic.milena@vpsle.edu.rs \\ Ivan Mihailović \\ Academy of Vocational Studies Southern Serbia, Leskovac, Republic of Serbia, mihailovic.ivan@vpsle.edu.rs \\ Ognjen Dimitrijević* \\ Academy of Vocational Studies Southern Serbia, Leskovac, Republic of Serbia, dimitrijevic.ognjen@vpsle.edu.rs
}

\begin{abstract}
Since the late 90 's, the existence and direction of causality between the capital market and foreign exchange market have attracted significant attention of theoretical and empirical researchers. This is because both of these financial variables have an indisputable role in the development of each country's economy. In this paper we use Johansen procedure and Granger causality test to examine the existence and direction of short-run and long-run dynamics between the leading stock market index BELEX15 and RSD/EUR exchange rate in Serbia. Using ADF test we find that both series are integrated of order one, and since the value of Johansen trace statistics confirmed the existence of cointegration, we have proceeded with estimation of the VECM model. According to our VECM model, the BELEX15 index adjusts to the long-run equilibrium relationship at a rate of $11.72 \%$ in each period, while the exchange rate adjusts to the long-run equilibrium relationship at a rate of $2.73 \%$. We also find that there is unidirectional causality and that the market index influences the exchange rate movements in the short-run in terms of Granger.
\end{abstract}

Keywords: cointegration, VECM, causality, stock market, exchange rate JEL classification: E44, G17

Сажетак: Још од касних 90-их, постојање и смер узрочности између тржишта капитала и тржишта девиза привлаче значајну пажњу теоријских и емпиријских истраживача. Ово из разлога што обе финансијске варијабле имају неспорну улогу у развоју економије сваке земље. У овом раду користимо Јохансенову процедуру и Гренџеров тест узрочности како бисмо испитали постојање и правац краткорочне и дугорочне динамике између водећег берзанског индекса BELEX15 и девизног курса RSD/EUR у Србији. Применом ADF теста проналазимо да су обе серије интегрисане реда један, а како је вредност Јохансенове статистике трага потврдила постојање коинтеграције, наставили смо са оценом VECM модела. Према нашем VECM моделу, индекс BELEX15 се прилагођава путањи дугорочне равнотежне везе по стопи од $11,72 \%$ у сваком периоду, док се девизни курс прилагођава путањи дугорочне равнотежне везе по стопи од 2,73\%. Такође смо открили да постоји једносмерна узрочност и да тржишни индекс краткорочно утиче на кретање девизног курса у смислу Гренџера.

Кључне речи: коинтеграција, VECM, узрочност, тржишни индекси, девизни курс JEЛ класификација: E44, G17 


\section{Introduction}

The relationship between stock market and exchange rate market has attracted substantial attention from researchers since the Asian Financial Crisis (Muhammad \& Rashid, 2002). Knowledge of this relationship, and the ability to predict the future trends for each variable can be exploited as a valuable forecasting tool by investors, on one side, in their everlasting attempts to earn greater profits, and authorities, on other side, in their attempts to maintain the stability of financial markets (Aydemir \& Demirhan, 2009).

There are two aspects of this relationship: short-term and long-term, and both of them are related to the Efficient Market Hypothesis (EMH). Efficient market hypothesis suggests that markets behave in an unpredictable manner and in accordance with the inflow of news which is random in nature (Abdullah et al., 2014). Thus, stock market and foreign exchange markets should show only short-term association. If these two are related over a longer period of time, this would suggest that they are predictable, thus making the efficient market hypothesis invalid (Mookerjee \& Yu, 1997). If so, occasional departures from long-run equilibrium can be used to earn profits by investors or to make adjustments by policy makers (Ali et al., 2011; Tomić \& Todorović, 2020).

The aim of this paper is to explore short-term and long-term relationship between the leading stock market index BELEX15 and the RSD/EUR exchange rate in Serbia. According to our knowledge, this is the first paper that investigates both short-run and long-run dynamics between the stock market and exchange rate in Serbia and finds that these two are cointegrated. The data period in our research ranges from January 2014 to December 2020. This study is based on ADF stationarity test, Akaike information criteria, Granger causality test and Johansen cointegration trace test. Based on our main findings, our objective is twofold. First, to estimate Vector Error Correction Model. We are particularly interested in coefficients of speed adjustment toward the long-run equilibrium relationship. Second, to test for significance of short-run coefficients in both VECM equations and determine direction of causality between the considered variables.

The structure of this paper is as follows. After brief introduction and existing literature overview, the third part provides methodology used in this paper. The fourth part contains data, descriptive statistics and results of econometric research. At the end of the paper, our conclusions are presented.

\section{Literature review}

A transition from a fixed to a flexible exchange rate regime took place in 1973. Since then, numerous studies have documented a causal relationship between stock prices and exchange rates (Abidin et al., 2013; Maysami \& Koh, 2000). However, the results of more recent research suggest that there is no long-run relationship between the two markets (Rahman \& Uddin, 2009).

Today, we can say with certainty that the empirical results concerning the relationship between the foreign exchange and the capital market are inconclusive (Agoraki et al., 2019; 
Aydemir \& Demirhan, 2009). This is because some studies support positive relationship between the two markets, whereas others find a negative association (Pan et al., 2007; Tsoukalas, 2003; Wajdi, 2019). Also, there are studies that could not find any relationship at all (Jorion, 1991; Nieh \& Lee 2001). Even more, we cannot be sure when it comes to the direction of causality.

Bahmani-Oskooee \& Sohrabian (1992) found bidirectional causality between S\&P500 index and the effective exchange rate of the dollar in the short-run. Their cointegration analysis revealed that there is no long-run relationship between two variables. Using a large sample and daily data, Ajayi \& Mougoue (1996) examined the relation between stock prices and exchange rates for eight developed countries. They found that an increase in stock prices has negative short-run, but positive long-run effect on domestic currency value. On the other hand, currency depreciation has negative short-run and long-run effect on the stock market.

Abdalla \& Murinde (1997) show unidirectional causality from exchange rates to stock prices in Korea, Pakistan and India, while stock prices Granger-cause exchange rates in the Philippines. Maysami \& Koh (2000) examined the long-term equilibrium relationships between the Singapore stock index and selected macroeconomic variables: exchange rate, interest rates, inflation, money supply, domestic exports, and industrial production. They concluded that changes in Singapore's stock market levels do form a cointegrating relationship with changes in price levels, money supply, interest rates, and exchange rates.

Using both the Engle and Granger two-step methodology and Johansen cointegration tests, Nieh \& Lee (2001) conclude in their paper that there is no significant relationship between stock prices and exchange rates in the G-7 countries. Tsoukalas (2003) studied the connection between stock prices and economic variables in Cyprus. He found strong evidence that prices and exchange rates are related. Ramasamy \& Yeung (2005) investigated the relationship between the exchange rates and stock markets in nine East Asian economies. They found that the direction of causality switches according to the length of period chosen.

Kurihara (2006) used monthly data of the Japanese economy to examine the association between macroeconomic variables and stock prices. He found that exchange rate influences Japanese stock prices. Rahman \& Uddin (2009) explored the dynamics between stock prices and exchange rates in three South Asia emerging countries. Their results show that there is no long-run relationship between stock prices and exchange rates. Also, they were not able to find any causality between these variables. Abdullah et al. (2014) found long-run relationship in Malaysia between Kuala Lumpur Composite Index and some key macroeconomic variables, including exchange rate.

As far as Serbia is concerned, Joksimović et al. (2020) investigated International Fisher Effect (IFE) and causality between nominal interest rate and RSD/EUR exchange rate. They found that $1 \%$ increase in the nominal interest rate differential, on average, lead to approximately a $0.3 \%$ offsetting change in the exchange rate. 


\section{Data and methodology}

As a framework for empirical analysis of the relationship between stock market and exchange rate market in Serbia, the vector autoregressive (VAR) model was applied in this paper. VAR is a multivariate time series model in which all variables are endogenous (Kozhan, 2009). It consists of a system of equations, where each variable in the system has one equation (Mills $\&$ Markellos, 2008). The right side of each equation includes a constant and the corresponding number of previous values of all variables in the system. The parameters of each equation in the VAR model are estimated by the method of Ordinary Least Squares (OLS). We define a VAR model of order $k$ and dimension $m$ as:

$$
X_{t}=c+\Phi_{1} X_{t-1}+\Phi_{2} X_{t-2}+\cdots+\Phi_{k} X_{t-k}+\varepsilon_{t}
$$

where $\boldsymbol{X}_{\boldsymbol{t}}$ is a vector of time series, $\boldsymbol{c}$ is a vector of a free term. $\Phi_{1}, \Phi_{2}, \ldots \Phi_{k}$ represent parameter matrices and $\varepsilon_{t}$ represents a vector of white noise whose individual components are uncorrelated time series of zero mean and finite variance $\varepsilon_{\boldsymbol{t}}: N_{m}(0, \Sigma) . m$ is the dimension of the VAR model and refers to the number of time series, while $k$ describes the autoregressive structure of time series included in vector $\boldsymbol{X}_{\boldsymbol{t}}$ (Mladenović \& Nojković, 2012).

By subtracting $\boldsymbol{X}_{\boldsymbol{t}-\mathbf{1}}$ from both sides of the equation (1) and substituting $\boldsymbol{\Delta} \boldsymbol{X}_{\boldsymbol{t}}=\boldsymbol{X}_{\boldsymbol{t}}-$ $\boldsymbol{X}_{t-1}$, VAR model can be represented in form of a vector error correction model (VECM):

$$
\Delta X_{t}=c+\Pi X_{t-1}+\Gamma_{1} \Delta X_{t-1}+\cdots+\Gamma_{k-1} \Delta X_{t-k+1}+\varepsilon_{t}
$$

where $\Pi=\Phi_{1}+\Phi_{2}+\cdots+\Phi_{k}-I, \Gamma_{j}=-\sum_{i=j+1}^{k} \Phi_{i}, j=1, \ldots, k-1$. When the matrix $\Pi$ is a singular matrix, two conclusions are possible. If $\operatorname{det}(\Pi)=0$, then the vector error correction model is reduced to the VAR model of the first differences and time series in the vector $\boldsymbol{X}_{\boldsymbol{t}}$ are not cointegrated. If $\operatorname{rang}(\Pi)=r, 0<r<m$, then $\Pi=\gamma \beta^{\prime}$, where $\gamma$ and $\beta$ are parameter matrices (dimension $m \times r$ ). In this case, time series in the vector $\boldsymbol{X}_{\boldsymbol{t}}$ are cointegrated, and a corresponding form of the VECM exists. $r$ is the number of independent cointegration equations. The elements of the matrix $\gamma$ can be interpreted as rate of adjustment coefficients toward the long-run equilibrium relationship. The elements of the matrix $\gamma$ represent cointegrating parameters (Kennedy, 2003).

Cointegration implies the stationarity of a linear combination of individually nonstationary time series (Engle \& Granger, 1987). The most common approach in testing the existence of cointegration and estimating cointegration parameters is known as the Johansen procedure (Johansen \& Juselius, 1990). In practice it comes down to testing the significance of the rank of the matrix $\Pi$. To determine the order (number of lags) $k$ in VEC model, we use the lowest value of any of the information criteria (AIC, SC, HQ) for the VAR $(k+1)$ model. The process of testing the existence of cointegration is sequential and ends with a phase in which the null hypothesis is not rejected for the first time. Testing is based on Johansen's corrected trace statistics, which is compared with the critical test value (Johansen, 1988, 1991). When testing, we use following hypotheses H0: no cointegration, as opposed to H1: there is at least one cointegrating relation. If the value of the test statistic is less than the critical value, the null hypothesis is not rejected and we conclude that cointegration does not exist and the testing process ends. Otherwise, we accept the alternative hypothesis and 
conclude that there is at least one cointegrating relation and move on to the next step. In the next step, we set up a new pair of hypotheses to determine whether there is exactly one cointegrating equation ( $\mathrm{H} 0)$ or perhaps there are two stationary combinations $(\mathrm{H} 1)$. The testing process ends with a phase in which the null hypothesis is not rejected for the first time.

The best-known causality test is the Granger causality test. We use Granger causality test to detect the direction of causality between variables, as well as to determine those variables that are exogenous in relation to a given set of variables (Granger, 1969; Granger et al., 2000). For time series $X_{1 t}$, we say that it causes in the sense of Granger $X_{2 t}$, if the values of $X_{2 t}$ can be predicted with greater precision on the basis of knowledge of the previous values $X_{1 t}$, than without them (Kozhan, 2009). Hypotheses we use in Granger's causality test are H0: $X_{1 t}$ does not cause $X_{2 t}$, as opposed to H1: $X_{1 t}$ causes $X_{2 t}$. If the null hypothesis is correct, it would mean that the equation for $X_{2 t}$ in VAR model, unnecessarily contains lagged variables of $X_{1 t}$. The null hypothesis of no causality is rejected at the chosen level of significance if the calculated value of the test statistic is greater than the corresponding critical value of the $\chi^{2}$ distribution with $k$ degrees of freedom $(k$ is the number of lags in VAR model).

In this paper we use monthly data from 01/01/2014 to 31/12/2020 (84 observations in total). Data for BELEX15 index are taken from the website of the Belgrade Stock Exchange, while data on the average exchange rate of the dinar against the euro (RSD/EUR) are taken from the website of the National Bank of Serbia. According to Jovanović (2019) Serbia has an insufficiently developed financial market characterized by small volume of turnover, a minor number of listed financial instruments and a poor market capitalization. BELEX15 is the index of the most liquid shares traded on the Belgrade Stock Exchange and serves as a basis for creating structured products and derivatives on the domestic and foreign markets. As for the exchange rate regime, a managed fluctuating exchange rate regime is in place in Serbia. A managed fluctuating exchange rate is a fluctuating exchange rate with a defined fluctuation range in accordance with the goals of monetary policy set by national central bank (Marjanac, 2020). The entire analysis was conducted in the Eviews 8.0 software package. Both time series were transformed into natural logarithms for the purposes of empirical analysis. Series marked as L_BELEX and L_FX represent the logarithmic values of BELEX15 and RSD/EUR time series. Series marked as D(L_BELEX) and D(L_FX) represent the first difference of the logarithmic values. L_BELEX $(-1), \operatorname{L} \_\operatorname{BELEX}(-2) \ldots$ represent the lagged values of the L_BELEX series.

\section{Empirical analysis and results}

Figure 1 gives us a visual idea of the series (non)stationarity at the level, as well as the tendency of the series to rise or fall over time. BELEX15 had ups and downs, but its value at the end of the observed period was above its value from the beginning. The greatest instability on the Serbian capital market, followed by a sharp decline in the value of the index, can be noticed at the turn of the first to the second quarter of 2020 and is caused by investors' 
uncertainty due to the COVID-19 epidemic. Regarding the RSD/EUR exchange rate, during the first half of the observed period, the value of the Serbian dinar has gradually decreased. In 2017 and 2018 we have the opposite movement. And finally, for the changes that have been happening since mid-2019, we can say that they are negligible. The highest value of the BELEX15 index was registered in the first month of 2020 (RSD 808.22), while the lowest value was registered in March 2014 (RSD 564.18). On the other hand, dinar had the highest value against the euro (115.38 RSD / EUR) in March 2014, while the lowest value of the dinar against the euro was 123.97 RSD in February 2017. Skewness of the BELEX15 index is negative (-0.33), while the skewness of the exchange rate is positive (0.51). Kurtosis of the both series is below three, telling us that the both distributions are flatter in relation to the normal distribution.

Figure 1. Movement of the BELEX15 index and the RSD-EUR exchange rate

L_BELEX

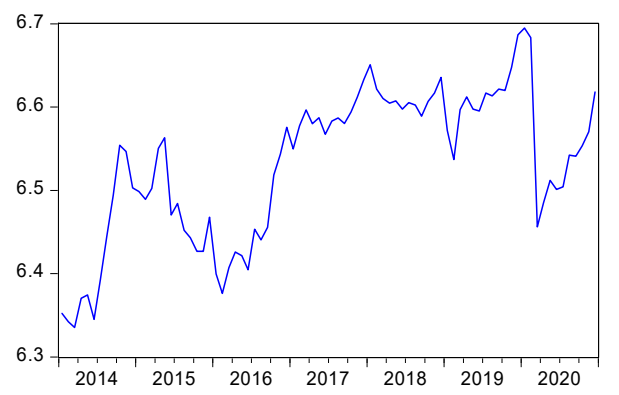

L_FX

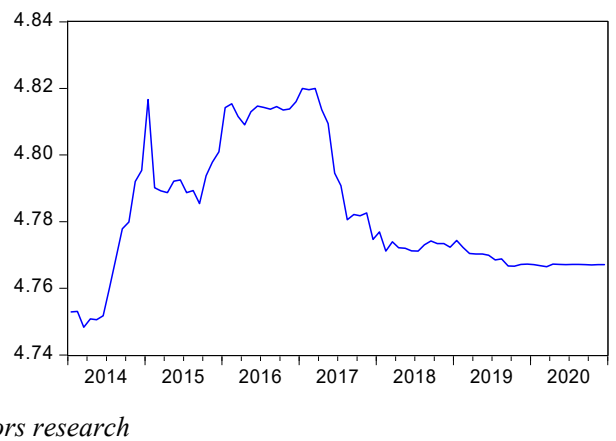

In Figure 2 we can see the first difference of the observed series. Note that both series oscillate around zero and that there are no rising and falling trends. Oscillating around zero indicates the stationarity of the first difference, i.e. both series at their level are probably I(1) processes. We are led to the same conclusion by observing the autocorrelation (ACF) and partial autocorrelation function (PACF), which we will not present here in the paper. Instead, we will verify this statement with the Augmented Dickey-Fuller (ADF) test.

Figure 2. First difference of the BELEX15 and the RSD-EUR exchange rate

\section{L BELEX}

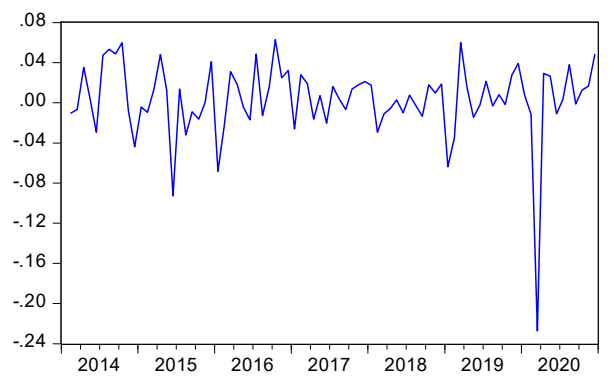

D L FX

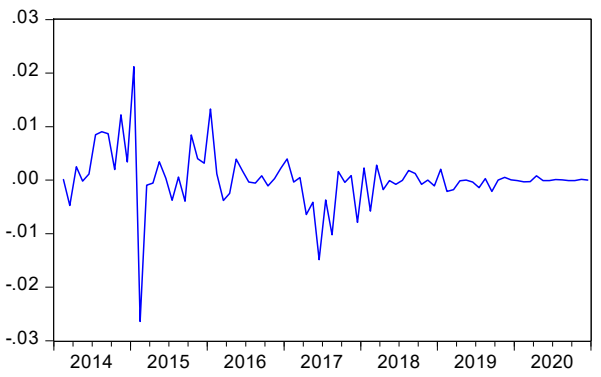

Source: Authors research 
In order to check the stationarity and existence of the unit root, we use the ADF unit root test (Dickey \& Fuller, 1979). We test H0: the series has a unit root, against the alternative H1: the series does not have a unit root (the series is stationary). If $p$ values above 0.05 are registered, we accept the null hypothesis, otherwise we reject it. Also, the registered $p$ values depend on whether we include a constant, linear trend or none of them in the model. The results of the ADF test for the level and the first difference are presented in Table1.

Table 1. Results of the ADF test for the level and first difference

\begin{tabular}{|c|c|c|c|c|c|c|c|}
\hline & \multicolumn{3}{|c|}{ ADF test (level, log data) } & & \multicolumn{3}{|c|}{$\begin{array}{c}\text { ADF test - (first difference, } \\
\text { log data) }\end{array}$} \\
\hline & \multicolumn{3}{|c|}{ p-value } & & \multicolumn{3}{|c|}{ p-value } \\
\hline & $\begin{array}{l}\text { none } \\
\text { inc. }\end{array}$ & $\begin{array}{c}\text { const. } \\
\text { only }\end{array}$ & $\begin{array}{c}\text { const }+ \\
\text { trend }\end{array}$ & & $\begin{array}{l}\text { none } \\
\text { inc. }\end{array}$ & $\begin{array}{c}\text { const. } \\
\text { only }\end{array}$ & $\begin{array}{c}\text { const }+ \\
\text { trend }\end{array}$ \\
\hline L_BELEX & 0,8705 & 0,1482 & 0,1956 & D(L_BELEX) & 0,0000 & 0,0000 & 0,0000 \\
\hline L_FX & 0,7637 & 0,4844 & 0,4810 & $\mathrm{D}\left(\mathrm{L} \_\mathrm{FX}\right)$ & 0,0000 & 0,0000 & 0,0000 \\
\hline
\end{tabular}

Source: the authors' research

All $p$ values are greater than 0.05 , meaning that we cannot reject the null hypothesis when it comes to the series level. However, after differentiation, all $p$ values become less than 0.05 , which means that after differentiation our nonstationary time series become stationary. Finally, we can conclude that both series possess unit root and are integrated of order one I(1). But, before we start estimating the VECM model, it is necessary to check the existence of cointegration. In order to determine the optimal number of lags to be included in model, we decided to use the AIC (Akaike, 1974). The results of the information criteria (AIC, SC, HQ) are given in Table 2.

Table 2. IC results

\begin{tabular}{|c|c|c|c|}
\hline $\begin{array}{c}\text { No. of } \\
\text { lags }\end{array}$ & AIC & SC & HQ \\
\hline 0 & -7.811036 & -7.749701 & -7.786523 \\
\hline 1 & -11.27487 & $-11.09086^{*}$ & $-11.20133^{*}$ \\
\hline 2 & -11.23472 & -10.92804 & -11.11216 \\
\hline 3 & -11.28176 & -10.85241 & -11.11017 \\
\hline $\mathbf{4}$ & $-\mathbf{1 1 . 2 9 3 8 2 *}$ & -10.74180 & -11.07321 \\
\hline 5 & -7.811036 & -10.54105 & -10.94610 \\
\hline
\end{tabular}

Source: the authors' research

We examined the existence of cointegration by applying the Johansen test and Pantula principle, which is explained below. Since we have two variables, we cannot have more than one cointegrating equation. Table 3 contains sample values of Johansen trace statistics, as 
well as registered $p$ values. If the registered $p$ value is less than 0.05 , we reject the null hypothesis (H0: there are no more than $n$ cointegration equations), where $n$, in our case, goes from zero to one.

Table 3. Johansen cointegration test results

\begin{tabular}{|c|c|c|c|c|c|c|}
\hline $\begin{array}{c}\text { H0 regarding the } \\
\text { number of CE } \\
\text { (cointegrating } \\
\text { equations) }\end{array}$ & \multicolumn{2}{|c|}{$\begin{array}{c}1^{\text {st }} \text { variant, Model with } \\
\text { intercept in CE, no } \\
\text { intercept in VAR }\end{array}$} & \multicolumn{2}{|c|}{$\begin{array}{c}2^{\text {nd }} \text { variant, Model } \\
\text { with intercept in CE } \\
\text { and VAR }\end{array}$} & \multicolumn{2}{|c|}{$\begin{array}{c}3^{\text {rd }} \text { variant, Model with } \\
\text { intercept and trend in } \\
\text { CE, no trend in VAR }\end{array}$} \\
\cline { 2 - 7 } & $\begin{array}{c}\text { Trace } \\
\text { statistic }\end{array}$ & p value & $\begin{array}{c}\text { Trace } \\
\text { statistic }\end{array}$ & p value & $\begin{array}{c}\text { Trace } \\
\text { statistic }\end{array}$ & $p$ value \\
\hline Zero CE & 25,7748 & 0,0078 & 25,1211 & 0,0013 & 27,5389 & 0,0308 \\
\hline At most one CE & 2,1305 & 0,7516 & 1,6973 & 0,1926 & 4,1037 & 0,7270 \\
\hline
\end{tabular}

Source: the authors' research

The Pantula principle was implemented by starting from the most restrictive model and observing the test results ( $p$ value or trace statistics value) when the null hypothesis is that there are no cointegrating equations. If we cannot reject the null hypothesis ( $p$ value greater than 0.05 or Trace statistic value greater than the critical value), we move on to the next model, and if we cannot reject the null hypothesis here either, we move on to the last model. If in at least one case we reject the null hypothesis, we move on to the next type of null hypothesis (that there is at most one $\mathrm{CE}$ ) and conduct an identical consideration. We stop the procedure when we first reject the null hypothesis. In our case, we managed to reject the null hypothesis in all three variants of the model. Now, we can conclude that there is one cointegrating relation and that it should be included in our model.

Having confirmed the existence of cointegration, we can now finally estimate VECM model. We have decided to estimate the $2^{\text {nd }}$ variant - model with intercept in CE and VAR. Our VECM model consists of two equations. The parameters of the cointegrating relation are highlighted at the beginning of each equation (given in the first bracket of the first and second equation, respectively). Note that the value of the adjustment coefficient in both equations is negative (-0.1172 and -0.0273 , respectively) and statistically significant $(|-2.1452|>1.96$ and $|-3.9375|>1.96$, which is necessary to have a valid economic interpretation. Our estimated VECM model is given in Table 4.

Table 4. VECM model

\begin{tabular}{|c|}
\hline Estimated coefficients for L_BELEX as a target variable: \\
\hline 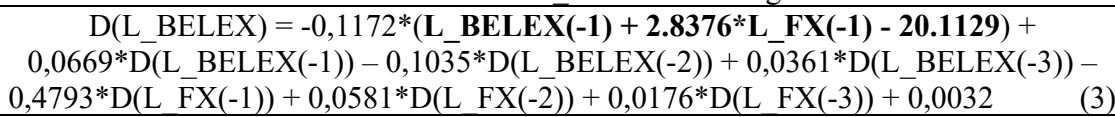 \\
\hline Estimated coefficients for L FX as the target variable: \\
\hline 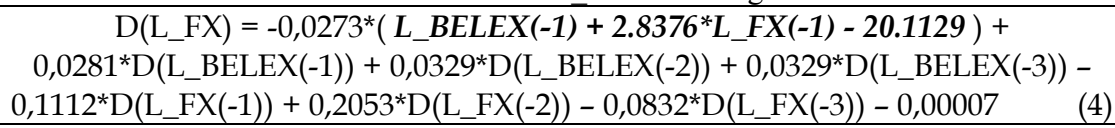 \\
\hline
\end{tabular}

Source: the authors' research 
The value of the adjustment coefficient (-0.1172) in equation (3) for the BELEX15 market index shows us that $11.72 \%$ of the deviation from the long-run equilibrium is adjusted in each period. In other words, the BELEX15 index adjusts to the long-run equilibrium relationship at a rate of $11.72 \%$ in each period. Also, a statistically significant value of the adjustment coefficient tells us that the exchange rate affects the movement of the market index in the long run. To examine the presence of short-term dynamics and determine whether the exchange rate affects the market index movements in the short term, we conducted Wald test. We tested the null hypothesis (coefficients are not statistically significant), against the alternative (at least one of the coefficients is statistically significant). Because of $\chi^{2}$ test statistics value $(0.3517)$ and $p$ value $(0.95)$, we cannot reject the null hypothesis. This further means that the coefficients of short-term dynamics are not statistically significant and that the exchange rate does not affect market index movements in the short run.

As for the second equation of our VECM model, exchange rate equation, the negative and statistically significant value of the adjustment coefficient shows us that in each period, exchange rate adjusts to the long-run equilibrium relationship at a rate of $2.73 \%$. As for the short-run dynamics, the results of Wald's test $(p$ value $=0.0103$ ) revealed that the coefficients are statistically different from zero, meaning that market index affects the exchange rate movements. Because all short-run coefficients have positive values, we can say that the increase in the market index leads to an increase in the exchange rate (decrease in the value of the dinar against the euro).

By conducting a Granger causality test, we come to the same conclusions regarding the short-term dynamics. The results of the Granger test are given in Table 5.

Table 5. Granger causality test results

\begin{tabular}{|c|c|c|c|}
\hline \multicolumn{4}{|c|}{ Dependent variable: D(L_BELEX) } \\
\hline Excluded & Chi-sq & df & Prob. \\
\hline D(L_FX) & 0.351664 & 3 & 0.9500 \\
\hline \multicolumn{4}{|c|}{ Dependent variable: D(L_FX) } \\
\hline Excluded & Chi-sq & df & Prob. \\
\hline D(L_BELEX) & $\mathbf{1 1 . 2 7 3 0 0}$ & $\mathbf{3}$ & $\mathbf{0 . 0 1 0 3}$ \\
\hline
\end{tabular}

Source: the authors' research

Further, we have examined the quality of our VECM model by checking for the presence of autocorrelation and distribution of the residuals. To examine the existence of autocorrelation in our VECM model, we conducted multidimensional Breusch-Godfrey LM autocorrelation test. The null hypothesis $\mathrm{H} 0$ (there is no autocorrelation of order $h$ in our model) was tested, against the alternative H1 (there is autocorrelation for any $\mathrm{i} \in\{1,2 . \mathrm{h}\}$ ). As all $p$ values are above 0.05 , we conclude that we cannot reject the null hypothesis, i.e. there is no cumulative autocorrelation. The results of the multidimensional BG autocorrelation test at five lags are given in Table 6. 
Table 6. BG autocorrelation test results

\begin{tabular}{|c|c|c|c|c|c|}
\hline Lag & 1 & 2 & 3 & 4 & 5 \\
\hline LM-Statistics & 2,5018 & 8,5383 & 6,8843 & 0,7426 & 2,9626 \\
\hline$p$ value & 0,6443 & 0,0737 & 0,1421 & 0,9460 & 0,5341 \\
\hline
\end{tabular}

Finally, we performed Lütkepohl multidimensional normality test. As the obtained $p$ value of this test is less than 0.05 , we conclude that the residues of our VECM model do not have normal distribution.

\section{Conclusion}

The purpose of this paper was to examine the existence and interdependence of short-term and long-term dynamics between the stock exchange index BELEX15 and the exchange rate $\mathrm{RSD} / \mathrm{EUR}$ in Serbia. Visual inspection and ADF unit root test confirmed that both series are integrated of order one. After determining the optimal number of lags, we conducted a Johansen cointegration test based on trace statistics to verify the existence of a long-run equilibrium relationship between the observed series. Since the value of trace statistics in all three tested variants confirmed the existence of cointegration, the next step was to estimate the VECM model. Our VECM model consists of two equations and the value of the adjustment coefficient in each equation is negative and statistically significant. Each month, BELEX15 index adjusts to the long-run equilibrium relationship at a rate of $11.72 \%$. On the other hand, according to the value of the adjustment coefficient in the second equation, exchange rate adjusts to the long-run equilibrium relationship at a rate of $2.73 \%$. Next, using Wald test and Granger causality test, we examined the presence of short-term dynamics between the two variables and found some evidence of unidirectional causality. The results of Wald's test revealed that the exchange rate does not affect the movement of the market index in the short run. However, since the coefficients of short-term dynamics were statistically different from zero in the second equation, we have concluded that the market index influences exchange rate in the short run. These results have been confirmed by a Granger causality test.

In this paper we have found evidence of both short-run and long-run relationship between stock prices and exchange rate in Serbia. The major implication of our findings is that investors can use information from one market, for instance stock market, to predict the behavior of the other market and earn profits. Also, policy makers can use exchange rate as a tool to attract foreign investment. Since our results at the same time support and oppose the results of other researches, they should not be taken for granted. We are aware that our results may be the product of deeper causes, macroeconomic factors such as government policy, expectations, degree of market liberalization or capital control etc. We are also aware that the significance of our results may be due to the chosen time horizon or data frequency. Therefore, further and broader analysis is needed. We suggest further research by using other economic variables such as interest rates, GDP growth rate, oil prices and money supply in exploring relationship between exchange rates and stock prices. 


\section{References}

Abdalla, I. S. A., \& Murinde, V. (1997). Exchange rate and stock price interactions in emerging financial markets: evidence on India, Korea, Pakistan and the Philippines. Applied Financial Economics, 7(1), 25-35. Doi: https://doi.org/10.1080/096031097333826

Abdullah, A. M., Saiti, B.,\& Masih, A. M. (2014). Causality between stock market index and macroeconomic variables: a case study for Malaysia. MPRA Paper 56987, University Library of Munich, Germany.

Abidin, S., Walters, C., Lim, K., \& Banchit, A. (2013). Cointegration between stock prices and exchange rates in Asia-Pacific countries. Investment management \& financial innovations, 10(2), 142-146.

Agoraki, M.-E.K., Georgoutsos, D.A., \& Kouretas, G.P. (2019). Capital markets integration and cointegration: testing for the correct specification of stock market indices. Journal of Risk and Financial Management, 12(4), 1-20, 186. Doi: https://doi.org/10.3390/jrfm12040186

Ajayi, R.A., \& Mougouė, M. (1996). On the dynamic relation between stock prices and exchange rates. Journal of Financial Research, 19, 193-207. Doi: https://doi.org/10.1111/j.1475-6803.1996.tb00593.x

Akaike, H., (1974). A new look at the statistical model identification, IEEE Transactions on Automatic Control, 19(6), 716-723. Doi: https://doi.org/10.1109/TAC.1974.1100705

Ali, S., Butt, B., \& Ur Rehman, K. (2011). Comovement between emerging and developed stock markets: an investigation through cointegration analysis, World Applied Sciences Journal, 12(4), 395-403

Aydemir, O., \& Demirhan, E. (2009). The relationship between stock prices and exchange rates: evidence from Turkey. International Research Journal of Finance and Economics, 1(23), 207-215. Doi: https://doi.org/10.1007/bf02296425

Bahmani-Oskooee, M., \& Sohrabian, A. (1992). Stock prices and the effective exchange rate of the dollar. Applied Economics, 24(4), 459-464. Doi: https://doi.org/10.1080/00036849200000020

Dickey, D.A., \& Fuller, W.A. (1979). Distribution of the Estimators for Autoregressive Time Series with a Unit Root. Journal of the American Statistical Association, 74(366), 427-431. Doi: https://doi.org/10.2307/2286348

Engle, R. F., \& Granger, C. W. J. (1987). Co-integration and error correction: Representation, estimation and testing, Econometrica, 55(2), 251-276. Doi: https://doi.org/10.2307/1913236 Granger, C. W. J., Huang, B., \& Yang C. (2000). A bivariate causality between stock prices and exchange rates: evidence from recent Asian flu. The Quarterly Review of Economics and Finance, 40, 337-354. Doi: https://doi.org/10.1016/S1062-9769(00)00042-9 
Granger, C.W.J. (1969). Investigating Causal relations by econometric models and crossspectral methods. Econometrica, 37(3), 424-438. Doi: https://doi.org/10.2307/1912791

Jorion, P. (1991). The pricing of exchange rate risk in the stock market. The Journal of Financial and Quantitative Analysis, 26(3), 363-376. Doi: https://doi.org/10.2307/2331212

Joksimović, M., Joksimović, D., \& Grujić-Vučkovski, B. (2020). A test of international fisher effect: researching from Serbia and the European Union. Ekonomika, 66(2), 49-61. Doi: https://doi.org/10.5937/ekonomika2002049J

Jovanović, M. (2019). Initial public offering as a source of financing and its significance for the development of the Serbian capital market. Ekonomika, 65(2), 99-108. Doi: https://doi.org/10.5937/ekonomika1902099J

Johansen, S. (1988). Statistical analysis of cointegration vectors. Journal of Economic Dynamics and Control, 12(2-3), 231-254. Doi: https://doi.org/10.1016/0165$\underline{1889(88) 90041-3}$

Johansen, S., (1991). Estimation and hypothesis testing of cointegrating vectors in Gaussian vector autoregressive models. Econometrica, 59(6), 1551-1580. Doi: https://doi.org/10.2307/2938278

Johansen, S., \& Juselius, K. (1990). Maximum likelihood estimation and inferences on cointegration - with applications to the demand for money. Oxford Bulletin of Economics and Statistics, 52(2), 169-210. Doi: https://doi.org/10.1111/j.14680084.1990.mp52002003.X

Kennedy, P. (2003). A guide to econometrics. MA: MIT press.

Kozhan, R. (2009). Financial Econometrics-With Eviews. Roman Kozhan \& Ventus Publishing. $\quad$ Retrieved 06/02/2021 from http://artemisa.unicauca.edu.co/ sidrobo/libros/FinancialEconometricsEviews.pdf.

Kurihara, Y. (2006). The relationship between exchange rate and stock prices during the quantitative easing policy in Japan. International Journal of Business, 11(4), 375-386.

Maysami, R., \& Koh, T.S. (2000). A vector error correction model of the Singapore stock market. International Review of Economics \& Finance, 9, 79-96. Doi: https://doi.org/10.1016/S1059-0560(99)00042-8

Marjanac, D. (2020). The effect of the exchange rate system on the economic growth of Bosnia and Herzegovina. Anali Ekonomskog fakulteta u Subotici, 43, 49-65. Doi: https://doi.org/10.5937/AnEkSub2001049M

Mills, T. C., Markellos, R. N., (2008). The Econometric Modelling of Financial Time Series. Cambridge: Cambridge University Press.

Mladenović, Z., \& Nojković, A. (2012). Primenjena analiza vremenskih serija. Beograd: Centar za izdavačku delatnost Ekonomskog fakulteta. 
Mookerjee, R., \& Yu, Q. (1997). Macroeconomic variables and stock prices in a small open economy: the case of Singapore. Pacific-Basin Finance Journal, 5(3), 377-388, Doi: https://doi.org/10.1016/S0927-538X(96)00029-7

Muhammad, N., Rashid, A. (2002). Stock prices and exchange rates: are they related? Evidence from South Asian countries. The Pakistan Development Review, Pakistan Institute of Development Economics, 41(4), 535-550. Doi: https://doi.org/10.30541/v41i4IIpp.535$\underline{550}$

Nieh, C. C., \& Lee C. F. (2001). Dynamic relationship between stock prices and exchange rates for G-7 countries. The Quarterly Review of Economics and Finance, 41(4), 477-490. Doi: https://doi.org/10.1016/S1062-9769(01)00085-0

Pan, M., Fok, R.C., \& Liu, Y.A. (2007). Dynamic linkages between exchange rates and stock prices: evidence from east Asian markets. International Review of Economics \& Finance, 16(4), 503-520. Doi: https://doi.org/10.1016/j.iref.2005.09.003

Rahman, L., \& Uddin, J. (2009). Dynamic relationship between stock prices and exchange rates: Evidence from three South Asian countries. International Business Research, 2(2), 197-174. Doi: https://doi.org/10.5539/ibr.v2n2p167

Ramasamy, B., Yeung, M.C.H. (2005). The causality between stock returns and exchange rates. Australian Economic Papers, 44(2), 162-169. Doi: https://doi.org/10.1111/j.1467$\underline{8454.2005 .00257 . \mathrm{x}}$

Tomić, N., \& Todorović, V. (2020). Potential negative implications of Libra cryptocurrency. Ekonomika, 66(1), 13-24. Doi: https://doi.org/10.5937/ekonomika2001013T

Tsoukalas, D. (2003). Macroeconomic factors and stock prices in the emerging Cypriot equity market. Managerial Finance 29(4), 87-92. Doi: https://doi.org/10.1108/03074350310768300

Wajdi, M. (2019). On the co-movements among stock prices and exchange rates cointegration: a VAR/VECM approach. Journal of Finance and Investment Analysis, 8(1), $61-75$. 
